\title{
STUDI DAMPAK TAVANGAN TELEVISI TERHADAP PERKEMBANGAN \\ PERILAKU SOSIAL ANAK
}

\author{
Novita Astarini ${ }^{1}$ \\ Solihin Ichas Hamid ${ }^{2}$ \\ Tin Rustini ${ }^{3}$
}

\begin{abstract}
ABSTRAK
Studi ini merupakan studi yang dilakukan berkenaan dengan dampak tayangan televisi sinetron terhadap perkembangan perilaku sosial anak usia 5 tahun di Perumahan Pondok Padalarang Indah Blok B3 No 28 RT 05 RW 22. Penelitian ini dilatar belakangi berdasarkan temuan peneliti mengenai perilaku sosial anak yang memiliki perilaku sosial kurang sesuai dengan tahap perkembangannya. Tujuan penelitian ini adalah untuk mengetahui profil perilaku sosial anak, kebiasaan anak dalam menonton televisi, peran orangtua dalam mendampingi anak menonton televisi dan dampak dari tayangan televisi sinetron terhadap perilaku sosial anak. Penelitian ini dilakukan dalam upaya mengungkap bahwa tayangan televisi sinetron saat ini memiliki kontribusi besar dalam mempengaruhi perilaku sosial anak terutama terhadap perilaku sosial anak berupa imitasi yang merupakan awal dari perilaku sosial anak, perilaku sosial anak terhadap teman sebaya dan perilaku sosial anak terhadap orang dewasa yang ada di sekitar anak.Metode penelitian yang digunakan adalah metode studi kasus dimana peneliti menjadi instrumen utama dalam melakukan penelitian, dengan cara analisis terperinci berdasarkan catatan lapangan, hasil dari observasi, dokumentasi serta melakukan wawancara mendalam, dengan sampel satu orang anak perempuan berusia 5 tahun. Hasil penelitian menunjukkan bahwa tayangan televisi sinetron memberikan dampak terhadap perkembangan perilaku sosial anak. Berdasarkan teori Walter Lippman Powerfull Effect mengungkapkan bahwa media masa termasuk televisi memiliki pengaruh yang besar serta mendalam bagi seseorang, dimana media mampu mempengaruhi manusia dan memberikan suntikan berupa ide, informasi bahkan propaganda untuk melakukan sesuatu, dalam konteks anak, propoganda adalah sebuah dorongan untuk anak mengikuti aksi- aksi yang ada dalam televisi. Dampak yang diakibatkan oleh tayangan televisi sinetron tersebut mempengaruhi perilaku sosial anak terutama pada pola perilaku sosial anak terhadap teman sebaya dan orang dewasa, yaitu perilaku anak melebihi perilaku usia anak 5 tahun, hal ini disebabkan oleh perilaku imitasi anak saat menonton televisi.
\end{abstract}

Kata kunci Tayangan Televisi Sinetron, Perilaku Sosial Anak Usia 5 Tahun

\footnotetext{
1 astavitano@gmail.com

${ }^{2}$ Dosen Kampus Cibiru

${ }^{3}$ Dosen Kampus Cibiru
} 


\section{A. PENDAHULUAN}

Pendidikan merupakan hal yang mendukung majunya kehidupan manusia, dengan pendidikan manusia akan lebih memiliki kebijaksanaan dalam hidupnya, karena pendidikan tidaklah hanya sebatas memberikan pengetahuan yang belum di ketahui. Dengan pendidikan manusia akan dipandang lebih mulia , karena manusia akan mampu membedakan mana yang baik dan buruk, pendidikan akan memberikan pandangan yang luas agar dapat memaknai hidup, bahwa hidup tidak hanya sebatas hidup, namun mampu menghasilkan karya yang dapat bermanfaat bagi orang lain. Dengan pendidikan manusia akan mampu menjalani hidup dengan baik, karena melalui pendidikan manusia memperoleh banyak pengetahuan, untuk membentengi diri dalam mengahadapi hidup yang semakin kompleks dengan segala hambatan- hambatan yang ada.

Menurut Undang- Undang No 20 Tahun 2003 Pasal 1 ayat 14 tentang Sistem Pendidikan Nasional, Pendidikan anak usia dini merupakan upaya pembinaan yang dilakukan untuk anak usia 0 sampai dengan 6 tahun, yang dilakukan melalui pemberian rangsangan pendidikan untuk membantu pertumbuha jasmai maupun rohani. Periode ini merupakan masa dimana anak memiliki kesempatan emas dalam hidupnya untuk mengenal dunia dan belajar banyak tentang kecakapan hidup. Pendidikan anak usia dini mengupayakan agar perkembangan anak bisa berkembangan secara optimal, dengan begitu pendidikan anak usia dini sangat memberikan kontribusi yang sangat baik untuk membekali anak di kehidupannya kelak. Pendidikan memang harus dimulai saat dini, mengingat bahwa dimasa ini anak dalam proses pembentukan baik atau buruknya, anak merupakan peniru yang ulung. Hal ini sejalan dengan pendapat Sears dkk ( dalam Riady, 2012. hlm 19 ) bahwa salah satu yang mempengaruhi perilaku tidak baik anak adalah melalui imitasi, yaitu manusia memiliki kecenderungan untuk meniru orang lain.

Perilaku anak perlu dikembangkan secara baik, mengingat bahwa perilaku anak sangat dominan terlihat di lingkungan. Perilaku anak yang baik adalah perilaku yang sesuai dengan tahapan perkembangan anak, jika tidak sesuai dengan tahapan perkembangan yang ada maka anak akan mengalami kesulitan. Jika perkembangan perilaku anak sesuai dengan tahapan perkembangan maka anak akan dapat melampaui perkembangan yang selanjutnya dengan baik, namun jika perilaku anak tidak sesuai dengan tahapan perkembangan maka anak akan mengalami hambatan pada perkembangan yang selanjutnya.

Pentingnya mengembangkan perilaku anak, tidak hanya melihat dari kepentingan secara medis, namun juga dilihat dari bagaimana seseorang dapat memenuhi tuntutan sosial dalam bentuk sikap dan perilaku yang sesuai dengan aturan dan norma yang ada. Anak yang memiliki perilaku yang sesuai dengan tahapan perkembangannyamenunjukkan keberhasilan anak yang berkembang dengan baik. tanpa mengetahui hal itu baik ataupun buruk, salah satu tempat dimana anak banyak mendapatkan sumber peniruan adalah tayangan- tayangan televisi.

Televisi merupakan salah satu media elektronik yang menyajikan ragam tayangan, baik berupa berita, tayangan- tayangan hiburan, tayangan edukatif, sampai pada tayangantayangan drama seperti sinetron dan $f t$. Dari kebanyakan tayangan televisi ini, yang banyak digemari sebagian orang adalah sinetron, bahkan dirumah- rumah yang memiliki anak usia dini, mereka menonton bersama ataupun tidak, tanpa penyortiran tayangan yang layak dikonsumsi untuk keluarga. Sehingga bagi anak- anak yang kurang 
mendapatkan pengontrolan dari orang tua, mendapatkan kesempatan luas untuk melakukan peniruan terhadap aksi-aksi yang selayaknya tidak dilakukan oleh anak, dan inilah salah satu yang menjadikan perkembangan perilaku anak menjadi terganggu karena pola perilaku mereka yang dipengaruhi oleh tontonan yang tidak layak untuk konsusmsi anak. Namun tidak semua tayangan televisi membawa dampak negatif, adapula tayangan edukatif yang memberikan anak akan banyaknya pengetahuan, namun sayangnya saat ini banyak orangtua yang acuh dan menganggap biasa hal yang justru bisa menjadi bumerang pada anak- anaknya, salah satunya adalah tayangan televisi seperti sinetron yang cenderung lebih banyak memberikan dampak negatif pada perkembangan perilaku anak.

Berdasarkan data Laporan Akhir Tahun 2015 KPID Jawa Barat mencatat, salah satu sanksi terbanyak dijatuhkan ke televisi adalah karena menayangkan siaran kekerasan, yakni 49 keputusan sanksi yang bersumber dari tayangan berita, film, dan sinetron. Keputusan sanksi KPID Jawa Barat itu pun tidak sekedar hasi temuan dengan rujukan dari UU Penyiaran dan P3-SPS teteapi juga dari pengaduan masyarakat. KPID Jawa Barat menerima 372 pengaduan yang 127 pengaduan atau sekitar $35 \%$ diantaranya pengaduan terhadap tindak kekerasn yang ditayangkan di televisi, Hikmat ( 2016, hlm. 26 ). Dalam konteks ini masyarakat pun memiliki pemahaman yang sama akan bahaya tindakan kekerasan yang tidak hanya memberikan informasi faktual, tetapi dapat menjadi inspirasi untuk terjadinya tindak kekerasan yang sama. Pengaduan masyarakat pun dapat dipersepsi sebagai bukti penolakan publik terhadap tayangan kekerasan ditelevisi.

Tayangan- tayangan tidak mendidik tersebut hadir disaat jam- jam anak masih aktif menonton televisi salah satu faktor mengapa anak menonton sinema tersebut. Pengawasan anak yang kurang dari orang tua yang disebabkan orang tua adalah pekerja juga menjadi salah satu penyebab anak dengan bebas menonton televisi terutama sinetron dengan tekun tanpa penyaringan- penyaringan sehingga anak dengan bebas menonotn dan menirukan adeganadegan yang ada dalam tayangan tanpa pemberian arahan dari orang tua yang seharusnya menjadi seorang pendamping serta pengarah saat anak meonton televisi.

Kebiasaan anak dalam menonton televisi tanpa pengontrolan waktu dari orang tua, kuranganya penyortiran tayangan televisi yang tidak layak dikonsumsi keluarga terutama anak, keegoisan orang dewasa sekitar anak yang asik menonton tayangan televisi yang seharusnya untuk dewasa dan membiarkan anak tetap menonton bersama mereka tanpa adanya pengarahan yang jelas menjadi salah satu penyebab tidak terkontrolnya pembendaharaan perilaku pada anak. Pengotrolan dan pengawasan orang tua dalam mendampingi anak saat menonton televisi menjadi salah satu alternatif agar perilaku anak terjaga dari pengaruh negatif tayangan televisi. Maka dari itu kesadaran dan pengawasan orang tua sangatlah penting, dengan begitu hal- hal negatif yang memungkinkan untuk ditiru oleh anak akan terminimalisir, karena dengan adanya orang tua saat menonton televisi berfungsi sebagai pengarahan perilaku yang seharusnya dilakukan anak, orang tua ada sebagai penerjemah bagi anak untuk mengetahui mana perilaku yang baik, dan mana perilaku yang salah, orang tua juga juga harus mampu menjadi evaluator yang baik bagi anak agar mampu meluruskan apa yang tidak sesuai dari perilaku anak.

Dengan demikian sebagai orang dewasa yang berada disekitar anak, selayaknya memiliki keprihatinan tersendiri jika anak- anak usia dini menjadi tidak baik perilakunya hanya karena peniruan- peniruan yang tidak baik yang mereka dapatkan dari media elektronik yaitu televisi. Kearifan orang tua dalam memelihara perilaku baik pada anak akan menjadi investasi yang sangat berharga untuk masa yang akan datang, baik bagi anak, orang tua, maupun orang yang berada di sekitarnya.

Berdasarkan latar belakang yang telah dipaparkan diatas maka peneliti menyusun beberapa rumusan masalah yang akan dijawab dalam penelitian ini. Rumusan permasalahan 
tersebut diantaranya adalah :

1. Bagaimana dampak tayangan televisi sinetron terhadap perkembangan perilaku sosial anak di Perumahan Pondok Padalarang Indah Blok B3 No 28 RT 05 RW 22 ?

2. Bagaimana kebiasaan anak dalam menonton tayangan televisi sinetron?

3. Bagaimana pendampingan orang tua dalam mendampingi anak menonton televisi ?

4. Bagaimana keterkaitan antara kebiasaan anak menonton televisi, pendampingan orang tua saat menonton televisi dengan perilaku anak?

Berdasarkan rumusan tersebut maka tujuan penelitian ini adalah untuk mengetahui :

1. Untuk mengetahui dampak tayangan televisi sinetron terhadap perkembangan perilaku sosial anak di Perumahan Pondok Padalarang Indah Blok B3 No 28 RT 05 RW 22

2. Untuk mengetahui kebiasaan dalam menonton tayangan televisi sinetron yang ditonton anak.

3. Untuk mengetahui pendampingan orang tua dalam mendampingi anak menonton televisi.

4. Untuk mengetahui keterkaitan antara kebiasaan anak menonton televisi, pendampingan orang tua saat menonton televisi dengan perilaku anak.

Perilaku adalah sesuatu yang dapat diamati baik berupa sikap, perbuatan ataupun tidakan yang dilakukan oleh seseorang. Perilaku juga timbul sebagai hasil interaksi manusia dengan lingkungannya sehingga mendorong manusia untuk melakukan sebuah perbuatan. Desmita ( 2012, hlm. 58 ) Behavior atau perilaku adalah kegiatan organisme yang dapat diamati dan bersifat umum mengenai otot- otot dan kelenjar- kelenjar sekresi eksternal sebagaimana terwujud pada gerakan bagian- bagian tubuh atau pada pengeluaran air mata, keringat. Perilaku dapat dikatakan sebagai respon dari sebuah rangsangan yang ditunjukkan dalam bentuk sikap, cara berpikir seseorang, dan cara seseorang memperlakukan orang lain.

Bandura menegaskan (dalam Syamsu, 2011. hlm. 132-133 ) bahwa perilaku manusia adalah hasil dari interaksi timbal balik yang terus menerus antara foktor- faktor penentu internal dan eksternal. Wujud dari faktor internal adalah berupa kognisi, persepsi, dan faktor lain yang dapat mempengaruhi kegiatan manusia. Sedangkan faktor eksternal adalah lingkungan, proses ini disebut sebagai "Reciprocal Determinism" yang menjadi prinsip dasar untuk menganalisis psikososial dalam berbagai tingkat yang kompleks, terentang dari perkembangan intrapersonal, tingkah laku interpersonal, fungsi interaksi organisasi sampai pada sistem sosial.

Manusia dapat mengontrol dirinya dan lingkungannya agar dapat menetukan perilaku yang akan dilakukan. Karena manusia dan kekuatan lingkungan akan terus berinteraksi dalam menetukan dan membentuk perilaku manusia.

Bandura (dalam Desmita, 2012. hlm. 59 ), mengemukakan 4 komponen penting dalam belajar melalui observasi yang diantaranya adalah :

1. Attention ( memperhatikan ), yaitu dimana manusia melakukan pengamatan terhadap suatu subjek yang dijadikan sebagai model.

2. Retention ( menyimpan/ mencamkan ), yaitu menyimpan pola yang telah di observasi, hasil pengamatan disimpan dan diwujudkan dalam bentuk perliaku individu yang sama dengan model tersebut

3. Motor Reproduction ( memproduksi gerak motorik ) setelah menyimpan pola perilaku yang telah di observasi, selanjutnya manusia harus memproduksi gerak motor yaitu berupa tingkah laku yang yang diperlihatkan sebagai hasil dari pengamatan dan penyimpanan

4. Vicarious- reinforcement ( ulangan- penguatan ) yaitu adanya perulangan perbuatan untuk memperkuat perbuatan yang sudah ada agar tidak hilang, inilah yang pada akhirnya akan menjadi pola kebiasaan yang akan menjadi sebuah perilaku.

Montessori ( 2008, hlm. 280 ), mengungkapkan dalam bukunya The Absorbent Mind, 
"Segala sesuatu yang harus kita orang dewasa lakukan adalah berperilaku sebagaimana biasanya, dan anak-anak, dengan meniru, akan tumbuh besar dengan cara yang sama". Demikian ungkapan Montessori pentingnya model dalam mempengaruhi perilaku seseorang terutama manusia. Dalam ungkapan tersebut dapat kita tarik kesimpulan bahwa setiap manusia idelanya adalah mengimitasi model yang memberikan teladan yang baik.

Adapun domain perkembangan sosial anak yang perlu dikembangkan, Kostenik menjabarkan ( dalam Nugraha, 2007. hlm 7.11) sebagai berikut :

1. Pengendalian tingkah laku secara internal

2. Pola - pola interaksi yang Positif

3. Sikap dan tindakan kooperatif

4. Sikap dan tindakan menolong

5. Sikap dan tindakan bertanggung jawab

6. Mengapresiasi dan mengahrgai persamaandan perbedaan individu

Tanggap terhadap lingkungan Menurut Effendy (dalam Rusman, 2012. hlm.185 ) yang dimaksud televisi adalah televisi siaran yang merupakan media dari jaringan komunikasi dengan ciri- ciri yang dimiliki media massa, yang berlangsung satu arah, komunikatornya melembaga, pesannya bersifat umum sasarannya menimbulkan keserempakan dan komunikasinya bersifat heterogen.

Televisi adalah sistem elektronik yang mengirimkan gambardiam dan gambar hidup bersama suara melalui kabel atau ruang. Sistem ini menggunakan peralatan yang mengubah cahaya dan suara ke dalam gelombang elektrik dan mengkonversinya kembali kedalam cahaya yang dapat dilihat dan suara yang dapat didengar ( Arsyad, 2014)

Dalam penelitian ini peniliti memfokuskan acara televisi yang akan dijadikan bahan dalam penelitian adalah tayangan televisi sinetron. Latief ( 2015,hlm 27 ) Sinetron ( Sinema Elektronik ) merupakan program televisi yang merupakan program drama, kata drama sberasal dari bahasa yunani dran, artinya bertindak atau berbuat. Menurut Suryo (dalam Latief, 2015 hlm 27 ) bahwa drama berasal dari bahasa Yunani kuno sekitar 6000 tahun sebelum Masehi, yaitu asal kata dari draomai yang artinya adalah perbuatan meniru suatu kejadian yang ditiru.

Keterkaitan antara tayangan televisi sinetron dan perilaku sosial anak dikemukakan oleh Vygotsky ( dalam Morrison, 2012. hlm. 77 ) Vygotsky meyakini bahwa perkembangan mental, bahasa dan sosial anak dipengaruhi oleh lingkungan sosial anak. lingkungan sosial yang di fokuskan dalam penelitian ini adalah media elektronik televisi dan budaya yang berperan didalamnya berupa tayangan- tayangan yang mulai berkembang dalam media elektronik televisi, seperti tayangan- tayangan televisi sinetron yang sudah sangat banyak ditayangkan. Berdasakan konsep Vygotsky maka nampak jelas bahwa tayangan televsi sebagai lingkungan sosial memiliki keterkaitan terhadap terbentuknya perilaku sosial anak.

Tayangan televisi ternyata juga memiliki dampak jangka pendek dan dampak jangka panjang hal ini diutarakan oleh Coyne \& Archer (2005) ( dalam Lan, dkk, 2010 ) bahwa terdapat dampak yang terlihat dalam jangka pendek yaitu perilaku sosial anak terutama dalam berinteraksi dengan orang lain selalu menggunakan agresi (kekerasan). Banyak anak yang tidak dapat mengontrol karena kekerasan yang ditirukannya melalui tayangan televisi telah menjadi suatu kebiasaan yang tidak bisa terlepas dari diri anak. Selain itu terdapat dampak jangka panjang seperti yang telah diungkap pada dampak jangka pendek bahwa kekerasan telah menjadi suatu kebiasaan, hal ini akan mendukung penuh anak untuk berani berbuat kriminal saat dewasa.

\section{B. METODE}

Metode penelitian yang digunakan dalam penelitian ini adalah jenis penelitian Studi 
Kasus. Dengan metode penelitian ini diharapkan dapat mengungkapkan fakta- fakta yang terdapat dalam kasus yang diteliti, yaitu fakta- fakta bahwa ada keterkaitan antara intensitas anak dalam menonton televisi, pendampingan orang tua dalam mendampingi anak menonton televisi dengan perilaku sosial anak. Pemilihan jenis penelitian ini dikarenakan tujuan dari penelitian ini sesuai dengan penelitian yang akan dilakukan. Hal ini seperti yang dikemukakan oleh Yin (2003) ( dalam Abidin, 2011. hlm. 209 ) kasus sebagai objek penelitian dalam penelitian studi kasus digunakan untuk memberikan contoh pelajaran dari adanya suatu perlakuan dalam konteks tertentu. Kasus yang dipilih dalam penelitian studi kasus harsu dapat menunjukkan terjadinya perubahan atau perbedaan yang di akibatkan oleh adanya perilaku terhadap konteks yang diteliti. Dengan berusaha menggali fakta-fakta yang menjadi penyebab dari adanya kasus tersebut diharapkan dapat memberikan pengetahuan baru dari dilakukannya penelitian ini.

\section{PEMBAHASAN}

Penelitian ini bertujuan untuk mengetahui dampak tayangan televisi sinetron terhadap perilaku sosial anak usia 5 tahun di Perumahan Pondok Padalarang Indah Jalan Alamanda Blok B3 No 28, jumlah subjek yang dijadikan subjek penelitian adalah satu orang anak usia 5 tahun, dengan jumlah informan yang mendukung kelengakapan data sebanyak 5 orang yang diantaranya adalah kedua orangtua dari subjek, dua orang tetangga dari subjek serta satu orang guru yang mengajar subjek di PAUD. Penelitian dilakukan dalam waktu 8 hari melalui pendekatan yang dilakukan sebelum penelitian secara berkala di setiap bulannya terhitung dari bulan November hingga Maret dan melakukan penelitian pada bulan April.

Melalui penelitian yang dilakukan, peneliti menemukan hasil yang telah dirumuskan sebelumnya menjadi fokus penelitian, beberapa fokus penelitian dalam penelitian ini yaitu dampak dari tayangan televisi terhadap perilaku sosial anak, kebiasaan anak menonton televisi, pendampingan orang tua dalam mengawasi anak menonton televisi serta keterkaitan antara kebiasaan anak menonton sinetron, serta pengawasan orang tua saat menonton sinetron terhadap perilaku sosial anak.

Dalam penelitian ini di temukan beberapa dampak tayangan sinetron bagi perilaku sosial anak, perilaku sosial anak yang difokuskan dalam penelitian ini adalah :

a. Perilaku Imitasi Anak

Melalui penelitian yang dilakukan terihat sekali dampak dari tayangan televisi terhadap perilaku imitasi anak terutama pada subjek yang diteliti, perilaku imitasi ini merupakan pola perilaku sosial pertama yang dilakukan anak setelah menonton tayangan televisi terutama tayangan sinetron yang kemudian membentuk anak menjadi sebuah kebiasaan yang terusmenerus dilakukan oleh anak. Perilaku imitasi ini sangat berdampak kurang baik ketika anak melakukan peniruan terhadap perilaku yang tidak baik. Beberapa peniruan yang dilakukan oleh anak setelah menonton tayangan televisi sinetron diantaranya adalah :

1) Menirukan perilaku yang dilakukan oleh model dalam tayangan sinetron

2) Menirukan sikap perilaku yang dilakukan oleh model dalam tayangan sinetron

3) Menirukan dalam bentuk gerakan fisik

4) Menirukan dalam bentuk Bahasa tubuh

5) Menirukan dalam bentuk verbal

Berdasarkan banyaknya peniruan yang dilakukan subjek, peniruan yang ditemukan dalam penelitian kebanyakan adalah perilaku yang melebihi batas anak usia 5 tahun, anak terlihat lebih matang dan dewasa sebelum waktunya, bahkan anak melakukan peniruan yang dilakukan orang dewasa seperti adegan- adegan percintaan yang seharunya anak usia 5 tahun belum pantas untuk mengetahui bahkan untuk menirunya. Hal ini sangat di tetang oleh norma agama yang berlaku melihat latar belakang agama subjek dan keluarganya adalah muslim 
dimana norma dan etika dalam berperilaku memiliki batasan tertentu yang tercantum dalam kitab, seluruhnya telah di atur baik perilaku antara orang tua dan anak bahkan dalam islam pun disampaikan batasan interaksi seorang laki- laki dan perempuan dalam Al- Qur'an Surat Al- Israa' Ayat 32 telah disampaikan larangan seorang muslim untuk tidak berbuat seronok , tidak mendekati zina ( zina mata, pikiran dan perbuatan ), dan memiliki batasan dalam berinteraksi. Hal ini perlu ditanamkan sejak dini, mengingat tayangan televisi masa kini justru banyak melanggar hal tersebut. Jika subjek dibiarkan terus menerus mengimitasi modelling yang tidak baik dari televisi tanpa pemberian arahan maka akan berdampak pada jangka panjang yang dapat merusak perilaku sosial serta moral subjek saat dewasa. Hal ini sejalan pula dengan yang dikemukakan oleh Monstessori (2008, hlm. 280) yang mengungkapkan bahwa perilaku terutama manusia idealnya adalah mengimitasi model yang memberikan modelling, hal ini nampak pada penelitian yang dilakukan yakni dimana subjek melakukan proses imitasi ketika menonton tayangan televisi, imitasi tersebut menjadi awal bagi subjek dalam memproduksi perilaku dalam proses beriteraksi dan besosialisi. Maka dari itu disini subjek membutuhkan model yang baik untuk ditiru agar subjek mampu memproduksi perilaku- perilaku positif sesuai dengan tahapan perkembanganya.

b. Perilaku Sosial Terhadap Teman Sebaya

Melalui hasil pengamatan yang intensif terhadap subjek nampak beberapa perilaku sosial anak yang terpengaruhi oleh sinetron terhadap teman sebayanya, anak cenderung egois, melakukan permainan- permainan dengan menirukan adegan- adegan yang ada di televisi seperti percintaan, berkelahi, mengejek, persaingan yang tidak sehat dan perilaku buruk lainnya. Setelah melalui pengamatan terlihat bagaimana anak sangat terpengaruh dengan sinetron sehingga memberikan dampak terhadap pergaulannya di lingkungan sosial terutama kepada teman sebayanya, beberapa hasil yang di temukan sebagai berikut :

1) Anak kurang mampu bermain dengan teman sebaya sesuai dengan konteks bermain anak.

2) Anak kurang mampu berkomunikasi dengan baik sesuai dengan konteks pembicaraan anak.

3) Anak kurang mampu berperilaku sesuai dengan usianya dengan teman sebayanya.

4) Anak Kurang mampu menegelola hubungan baik dengan teman sebayanya

Beberapa temuan yang lainnya adalah anak yang secara berlebih menonton sinetron menyebabkan hubungan dengan teman sebaya menjadi kurang sehat, dimana anak menjadi lebih matang dari umur yang seharusnya, sedangkan seharusnya anak bisa bergaul dengan temannya sesuai dengan usia 5 tahun. Anak menjadi terlihat lebih dewasa dan kurang wajar dalam pergaulan teman sebaya.

c. Perilaku Sosial Terhadap Orang Tua (Orang Dewasa Sekitarnya)

Melalui hasil penelitian, perilaku subjek yang intens dalam menonton sinetron mendapatkan pengaruh pengaruh negatif yang kurang baik terhadap perilaku sosial anak terutama dalam berinteraksi dengan orang dewasa sekitarnya termasuk dengan orang tua. Subjek melakukan peniruan yang diterima melalui tayangan televisi sinetron dan memproduksi perilaku tersebut dalam pergaulan terutama dalam berinteraksi dengan orang tua, anak cenderung tidak sopan dan lebih dewasa dibandingkan usianya. Beberapa perilaku sosial yang tidak sesuai sebagai hasil peniruan sinetron di antaranya adalah :

1) Anak kurang mampu berinteraski baik dengan orang tua

2) Anak kurang mampu menujukkan perilaku yang santun terhadap orang tua.

3) Anak kurang mampu berkomunikasi dengan baik kepada orang tua sesuai dengan konteks percakapan anak terhadap orang tua.

4) Anak kurang mampu menunjukkan perilaku positif terhadap orang tua sesuai dengan konteks perilaku anak terhadap orang tua.

Melihat pemaparan hasil penelitian tersebut terlihat bahwa perilaku subjek tidak sesuai 
dengan perilaku anak usia 5 tahun yang seharusnya hal ini dapat dilihat dari Tingkat Pencapaian Perkembangan Sosial Emosional Usia 5 sampai <_ 6 Tahun Peraturan Menteri 58 Tahun 2009 yang diantanya adalah :

1) Bersikap Kooperatif dengan teman

2) Mengekspresikan emosi yang sesuai dengan kondisi yang ada ( senang- sedih- antusias )

3) Mengenal tata krama dan sopan santun sesuai dengan nilai sosial budaya setempat

4) Memahami peraturan dan disiplin Sedangkan melihat dari konsep

Peraturan Menteri Nomor 146 tahun 2014 perilaku sosial anak usia 5 tahun seharusnya adalah :

1) Memiliki perilaku yang mencerminkan sikap rendah hati, dan santun kepada orang tua, pendidik, dan teman

2) Memiliki perilaku yang mencerminkan sikap peduli mau membantu jika dimainta bantuannya

3) Memiliki perilaku yang mencerminkan sikap taat terhadap aturan sehari- hari untuk melatih kedisiplinan

4) Memiliki perilaku yang mencerminkan sikap sosial.

Melihat pemaparan perilaku sosial yang seharusnya di tunjukkan dalam perkembangan anak usia 5 tahun, dalam penelitian ini peneliti justru menemukan bahwa subjek cenderung belum mampu memenuhi perkembangan yang seharusnya sesuai dengan tingkat pencapaian perkembangannya.

Ditinjau dari esensi sosialisi yang di kemukakan Vygotsky ( dalam Morrison, 2012. hlm. 77 ) Vygotsky meyakini bahwa perkembangan mental, bahasa dan sosial anak dipengaruhi oleh lingkungan sosial anak. Selain itu Vygotsky juga meyakini bahwa nilainilai sosial dan budaya berperan penting dalam proses belajar anak. Dalam penelitian ini lingkungan sosial subjek mempengaruhi bagaimana perilaku sosial subjek terbentuk, lingkungan sosial yang di fokuskan dalam penelitian ini adalah media elektronik televisi dan budaya yang berperan didalamnya berupa tayangan- tayangan yang mulai berkembang dalam media elektronik televisi, seperti tayangan- tayangan televisi sinetron yang sudah sangat banyak ditayangkan. Dalam kasus ini subjek sangat kuat dipengaruhi oleh lingkungan sosialnya terutama lingkungan sosial yang berupa media elektronik televisi

Ditinjau dari esensi proses terbentuknya perilaku pada manusia oleh Bandura (dalam Desmita, 2012. hlm. 59 ) yang dikemukakan dalam bagian tinjauan pustaka, bahwa anak memunculkan perilaku sosialnya setelah mereka mengalami berbagai rentetan proses yang mereka lalui sehingga terbentuklah perilaku yang muncul sebagai hasi dari produksi rangkaian proses tersebut. Rangkaian yang membentuk perilaku anak tersebut adalah :

1. Attention ( memperhatikan ) dimana dalam penelitian ini sejalan dengan proses subjek dalam menonton tayangan televisi sinetron.

2. Retention ( Menyimpan/ Mencamkan ) dimana dalam penelitian ini subjek menyimpan segala sesuatu yang mereka lihat dan peroleh dari tayangan televisi sinetron.

3. Motor Reproduction ( Memproduksi gerak motorik) dalam penelitian ini sejalan dimana anak memproduksi gerak motor yaitu berupa tingkah laku yang diperlihatkan sebagai hasil observasi subjek terhadap tayangan televisi sinetron yang mereka tonton, tingkah laku tersebut berupa perilaku sosial yaitu berupa imitasi, perilaku sosial terhadap teman sebaya dan perilaku sosial terhadap orang dewasa di sekitar subjek .

4. Vicarious- reinforcement ( ulangan- pengutan ) sejalan dengan penilitian ini tahap ini dapat dilihat dimana subjek selalu mengulang tingkah laku yang subjek amati dan simpan, subjek terus- menerus mengulang tingkah laku tersebut hingga akhirnya menjadi kebiasaan yang lama kelamaan membebtuk perilaku anak, terutama perilaku sosial subjek. 
Berkaitan dengan dampak tayangan televisi bagi perilaku subjek, faktor- faktor lain yang ditemukan peneliti yakni adalah kebiasan subjek dalam menonton televisi, dalam penilitian ini juga difokuskan kedalam beberapa pengamtan berkaitan dengan kebiasaan subjek menonton televisi, pengamatan tersebut tertuju pada intensitas subjek dalam menonton televisi, durasi subjek dalam menonton televisi, jumlah sinetron yang ditonton dalam sehari, dan jenis sinetron yang ditonton oleh subjek, berdasarkan data yang didapatkan melelui pengamatan secara intensif dapat dilihat kebiasaan menonton anak sebagai beerikut :

1. Intensitas anak dalam menonton televisi adalah sangat sering.

2. Durasi anak dalam menonton televisi lebih dari 1 jam perhari.

3. Jumlah sinetron yang ditonton oleh anak adalah lebih dari 1 sinetron.

4. Jenis sinetron yang ditonton oleh subjek sebagian besar adalah sinetron remaja yang bertema percintaan, hedonisme, dan kekerasan.

Melihat dari pembahasan tersebut kebiasaan subjek dalam menonton televisi jauh dari ideal, hal ini didasarkan pada data yang terungkap dalam Hurlock ( 1978, hlm. 343 ) yang merupakan informasi mengenai waktu yang digunakan anak pada berbagai usia untuk menonton televisi setiap hari, yang bersumber dari H. R. Marshall, (Relations between home experience and children's use of language in play interactions with peers. Psychological Monographs, 1961, 75 n0. 5. Dengan izin ), waktu ideal anak dalam menonton televisi adalah sebagai berikut :

1. Durasi menonton anak usia 2,5 - 3, 5 tahun : 30 menit/ hari

2. Durasi menonton anak usia 3,5 - 4,5 tahun : 50 menit/ hari

3. Durasi menonton anak usia 4,5 - 5,5 tahun : 90 menit/ hari

4. Durasi menonton anak usia 5,5 - 6,5 tahun : 105 menit/ hari

Berdasarkan kondisi ideal tersebut subjek telah melebihi batas normal anak usia 5 tahun dalam menonton televisi, dan ini merupakan kebiasaan yang tidak sehat jika dibiarkan, subjek bahkan bisa mengahabiskan waktu selama berjam- jam untuk menonton tayangan televisi sedangkan batas maksimal anak dalam menonton tevelisi usia 4,5- 5,5 tahun hanya sebanyak 90 menit perhari.

Selain durasi waktu yang perlu diperhatikan hal lain yang perlu ditelaah adalah tontonan yang ideal bagi anak, melihat dari hasil penelitian ini subjek lebih banyak menonton tayangan - tayangan remaja dan dewasa serta bertem percintaan, hedonisme dan kekerasan. Padahal idealnya tontonan bagi anak usia 5 tahun adalah:

1. Tayangan yang melibatkan dramatisasi hewan dan orang

2. Tayangan yang melibatkan musikal

3. Tayangan kartun edukatif

4. Tayangan komedi sederhana

5. Tayangan yang Informatif Terdapat faktor lain yang

mempengaruhi perilaku buruk terutama perilaku sosial subjek akibat sinetron yaitu kurangnya pengawasan orang tua terhadap anak saat menonton. Dalam penelitian ini orang tua sangat minim dalam mendampingi anak dalam menonton televisi padahal pendampingan orang tua sangat penting dilakukan, mengingat anak belum mampu dalam menyeleksi perilaku- perilaku yang terdapat dalam tayangan televisi terutama perilaku yang kurang baik. Perilaku anak yang terbentuk secara alamiah dalam menirukan perilaku yang kurang baik pada televisi ini sejalan dengan yang dikemukakam oleh Piaget ( dalam Morrison, 2012 ) dimana anak mengkontruk pengetahuannya sendiri sebagai pengalaman anak dalam mengorganisir, menyusun dan menyusun ulang sesuai dengan banyaknya kumpulan pengetahuan yang mereka miliki yang selanjutnya dimodifikasi dan diperkaya seiring dengan interaski lingkungan sosial serta kondisi sosial.

Pemikiran Piaget sangat memperkuat penelitian ini bahwa anak sangat membuthkan 
pengawasan orang tua dalam menonton televisi dimana orang tua membantu anak dalam menyusun kembali pengetahuan yang mereka dapatkan dari tayangan televisi serta memodifikasi skema yang telah dimiliki anak jika skema yang dimiliki anak belum benar. Karena pada realitanya pengetahuan yang anak dari televisi lebih banyak dampak negatifnya untuk era saat ini, maka inilah fungsi dan peranan penting orang tua dalam mendampingi anak menonton televisi. Proses anak dalam menerima informasi berdasarkan teori piaget yang berkaitan dengan menonton televisi sebagai berikut :

1) Asimilasi yaitu tahapan dimana anak mendapatkan pengalaman baru dan ini merupakan pengalaman yang sangat penting untuk anak dalam membentuk awal pengetahuan anak, sejalan dengan penelitian ini pengalaman baru anak didapat dari anak menonton televisi, mengamati segala macam yang terdapat dalam tayangan televisi dan menyimpannya sebagai dasar pengetahuan subjek.

2) Akomodasi merupakan proses merubah skema lama atau pengetahuan lama yang telah didapat oleh anak dan beradaptasi dengan situasi baru, namun dalam penelitian ini justru anak mengalami kesulitan dalam proses akomodasi terutama dalam merubah skemanya mengenai perilaku sosial yang subjek dapatkan dari tayangan televisi sinetron dikarenakan kurangnya bimbingan orang tua, sedangkan proses akomodasi ini sangat penting agar anak mampu mengklasifikasikan perilaku yang baik dan buruk. 3) Keseimbangan merupakan proses dimana asimilasi dan akomodasi berjalan beriringan secara baik, sehingga anak memiliki konsep pengetahuan secara baik dan utuh, namun dalam kasus ini justru anak sulit untuk melakukannya secara seimbang sehingga subjek tidak mampu membedakan konsep perilaku baik dan buruk sehingga menyebabkan perilaku sosial subjek dalam berinteraski dengan teman sebaya dan orang dewasa sekitarnya kurang sesuai dengan usianya Pemaparan pembahasan diatas menunjukan bahwa tayangan televisi memilki dampak dan pengaruh yang besar terhadap perkembangan perilaku sosial anak trutama perilaku anak dalam mengimitasi, perilaku sosial saat berinteraksi dengan teman sebaya dan perilaku sosial saat berinteraksi dengan orang dewasa yang ada di sekitar anak, beberapa faktor pun mendukung terbentuknya perilaku sosial anak, yaitu kebiasaan anak dalam menonton televisi serta pendampingan orang tua saat anak menonton televisi yang ternyata memberikan kontribusi yang cukup besar.

\section{PENUTUP}

Berdasarkan penelitian yang dilakukan dan pemaparan data yang telah dianalisis mengenai dampak tayangan televisi sinetron terhadap perilaku sosial anak 5 tahun di Perumahan Pondok Padalarang Indah Blok B3 No 28 dapat dikemukakan beberapa hal sebagai simpulan. Simpulan ini menggambarkan rumusan masalah yang telah dibuat, yaitu:

1. Dampak tayangan televisi sinetron terhadap perkembangan perilaku sosial anak di Perumahan Pondok Padalarang Indah Blok B3 No 28 RT 05 RW 22 menyebabkan perilaku anak menjadi lebih dewasa dibandingkan usianya, dari cara mereka berinteraksi dengan orang tua, orang dewasa yang ada disekitarnya dan teman sebayanya, ini merupakan dampak yang diawali dengan proses sosial awal anak berupa imitasi baik berupa perilaku, sikap, gerakan fisik, bahasa tubuh, dan juga peniruan secara verbal sehingga mempengaruhi anak dalam berperilaku sosial di lingkungannya. Anak menyaksikan tayangan televisi sinetron, kemudian menyimpannya sebagai hal baru yang mereka terima, kemudian menyimpannya, dan mengalami penguatan berupa konsistensi anak dalam menonton televise sinetron serta menampakkannya sebagai sebuah perilaku yang dilakukan anak sebagai hasil pengamatan mereka melalu seringnya menonton tayangan televisi 
sinetron.

2. Kebiasaan anak dalam menonton televisi subjek memiliki kebiasaan menonton televisi yang kurang baik, melihat dari intensitas anak menonton televisi yang sangat panjang dan berlebih dan berbagai tayangan televisi sinetron yang kurang baik untuk di tonton subjek yang berusia 5 tahun justru nampak selalu ditonton di setiap harinya.

3. Pendampingan orang tua terhadap subjek dalam menonton televisi memiliki pendampingan yang kurang baik, melihat dari keseharian orang tua yang kurang nampak dalam mendampingi anak dalam menonton televisi sehingga pengontrolan orang tua terhadap apa yang ditonton anak sangatlah minim. Orang tua sangat jarang nampak dalam memilihkan program yang baik untuk anak, tidak menemani anak saat menonton televisi, orang tua tidak bertindak sebagai evaluator saat menonton televisi, tidak mengawasi adegan- adegan yang disaksikan anak saat menonton televisi, dan tidak terjalinnya komunikasi sehat dan efektif dengan anak saat menonton televisi.

4. Terdapat keterkaitan antara tayangan televisi sinetron, kebiasaan subjek dalam menonton tayangan televisi sinetron dengan pendampingan orang tua terhadap subjek saat menonton televisi terhadap perilaku sosial subjek yang tidak sesuai dengan usia perkembanganya yaitu usia 5 tahun.

\section{DAFTAR PUSTAKA}

Abidin, Y. (2011). Penelitian pendidikan dalam gamintan pendidikan dasar dan PAUD.Bandung: Rizqi Press.

Arsyad, A. (2014). Media pembelajaran. Jakarta : PT RajaGrafindo Persada.

Departemen Pendidikan dan Kebudayaan. (2014). Peraturan pemerintah no 146 kurikulum 2013 pendidikan anak usia dini. Jakarta: Depdikbud

Desmita. (2012). Psikologi perkembangan. Bandung : PT Remaja Rosdakarya.

Departemen Pendidikan dan Kebudayaan. (2009). Peraraturan Menteri pendidikan Republik Indonesia nomor 58 tahun 2009. Jakarta : Depdikbud

Hikmat, M. M. ( 2016, 4 Januari 2016 ). Tahun kekerasan lembaga penyiaran. Pikiran Rakyat, $h \operatorname{lm} 26$

Hurlock. B. H. (1980). Psikologi perkembangan suatu pendekatan sepanjang rentang kehidupan edisi kelima. Jakarta . Erlangga

Lan, K. L., Abdullah, M. C., dkk. (2010). Understanding media violence and the development of aggressive behaviour of school children. Procedia - Social and Behavioral Sciences, 7(2), 522- 527.

Montessori, M. (2008). The absorbent mind, pikiran yang mudah menyerap. Yogyakarta : Pustaka Pelajar.

Morrison, G.S. (2012). Dasar- dasar pendidikan anak usia dini (PAUD). Jakarta:PT Indeks.

Nugraha. A \& Rahmawati. Y. (2007). Metode pengembangan sosial emosional. jakarta: Universitas Terbuka

Riady, S. (2012). Analisis perilaku agresif anak usia dini di kelompok a taman kanak- kanak arum sari. (Skripsi). Universitas Pendidikan Indonesia, Bandung.

Rochman. F. (1993). 160 Ayat- ayat hukum Al- Qur'an. Surabaya : Apollo

Rusman, dkk. (2012). Pembelajaran berbasis teknologi informasi dan komunikasi. Jakarta: PT RajaGrafindo Persada. 